Article

\title{
A Comparison of Solar Photovoltaic and Solar Thermal Collector for Residential Water Heating and Space Heating System
}

\author{
Md. Habibur Rahaman', M. Tariq Iqbal² \\ Faculty of Engineering, Memorial University of Newfoundland, St. John's, NL, Canada. \\ Correspondence: Md. Habibur Rahaman, mhrahaman@mun.ca, Tel: +1-709-219-5007
}

\begin{abstract}
Almost all single-family detached house in Canada consume huge electricity for space heating and domestic hot water (DHW) purposes. There are many possibilities to design an energyefficient house. A solar water heating system can be used for domestic water and space heating. Water temperature can be kept constant always by connecting a heat pump or oil burner because solar energy is intermittent. Proper and optimized solar photovoltaic and collector design, tank design, heat pump selection, house insulation, total demand calculation in each section are essential. EnergyEfficient house design has been proposed with water heating and space heating system and compared with the existing system, solar PV based systems, and solar collector based system. The tracking and non-tracking based solar thermal collector based and the solar photovoltaic based system has been compared in this paper and investigate the suitable one for practically applicable and acceptable by the people. Simulation has been done by using the PolySun software. It found that by implementing the proposed PV based system with tracking is highly suitable considering lower cost, high output power, flexibility, easy installation.
\end{abstract}

Keywords: solar photovoltaic; thermal collector; water heating; space heating; performance; cost analysis

\section{Introduction}

Canada is the world-leading country with the large landmass and diversified geographical structure with lots of renewable energy resources. The sun is an excellent source of renewable energy. Solar PV energy is the fastest-growing sources of electricity in Canada. Generally, the solar potential in some Canadian cities is comparable with that of many major cities in the world. From the sun, the photovoltaic cell can produce electricity, and solar collector can generate heat. Currently, the residential, commercial solar breakeven is comparatively much less than the grid electricity prices, e.g., average 6.8 cents/kWh due to the lower price of materials and the lower overall installation cost [1]. It assumed that the rooftop PV or collector panel could mitigate about half of Canada's residential energy requirement [2]. Solar collector system is using for water heating, and space heating purposes and the solar PV is using for on-grid or off-grid.

The price of photovoltaic (PV) technology is significantly decreased over the last few decades, and the efficiency of the PV panel increased. Some manufacturers demanded that the efficiency is around $23 \%$, which is available in the market at the lowest prices. In the whole Canadian power generation, solar energy is contributing more than $1 \%$, and the total generation is more than $3000 \mathrm{MW}$ [3]. There are more than 138 numbers of solar PV farms in Canada with a capacity of at least $1 \mathrm{MW}$, totaling over $1700 \mathrm{MW}$ and the rest of the energy are producing from the rooftop PV panel. This heat energy 
can be used to provide domestic hot water (DHW) supply, and space heating purposes as almost all Canadian single-family houses are using electricity for both of them. Solar PV and solar collector can mitigate this energy demand partially or fully.

Thermal energy storage (TES) system is also prevalent and practical structures to store thermal energy for space heating and domestic hot water supply in different mediums such as water, latent heat, sensible heat and many more. In this research, the water-based TES system has been considered. Because of several advantages nowadays, the active integrated system (controlled type) is used to a large extent to reduce the energy mismatch between supply and demand through a controller [4]. Canada's Energy Future (2018) highlighted that the present per capita greenhouse emission (GHG) in around $22 \%$ but they are thinking to reduce to below $5 \%$ by 2030 [5]. It is found from the government studies that around 5\% energy will be generated from solar by the year 2025 [6]. Solar energy can make an important role in it.

\section{Literature Review}

Renewable energy sources provide more than $17 \%$ of Canada's total primary energy supply currently [7]. Lots of research is going on solar thermal energy-based energy-efficient building worldwide. M. Ghorab et al. [8] verified that the solar fraction, as well as output, would increase proportionally with the increase of solar collector area. They also suggested that hybrid residential energy end-use and emissions model is beneficial to make an efficient detached house. M. C. Rodríguez-Hidalgo et al. [9] investigated in his research that the multisource heat pump, heat exchangers or solar collectors are the efficient, cheapest and easy way to produce heat for space heating for long-term performance. S.Z. Mozabieh et al. [10] highlighted that the cumulative lifecycle energy and carbon analysis, as well as energy payback periods and net energy ratios, are also crucial for making an energy-efficient house.

A single-family house can make energy-efficient even net-zero carbon emission by using an allelectric solution. J. L. Garcia et al. [11] mentioned that the solar collector based DHW system performance depends on water flow rate, draw time and duration, city water temperature, control of water circulation loop, and system layout. From their experiments, they found that most of the collected energy goes to the loads. The used a concentrating solar collector and rock-bed storage with air as a working medium for a long-term house heating system. Authors [11] suggested making an energy-efficient house by improving the house design parameters such as walls, insulation, windows, and ceiling fan, and so on. In this research, a solar thermal energy-based space heating and DHW system have been designed and analyzed for a single-family residential house.

Some Universities in Canada are doing some research relating to energy storage in summer and supply the stored energy in the extreme wintertime. Thus electricity demand will be reduced. For instance, the University of Ontario Institute of Technology built a low-temperature borehole thermal energy storage system (BTES) system in 1990 which has 384 holes, each 213 meters (700 feet) deep, provide the basis for a highly efficient heating and cooling system for eight University buildings [13]. One of the significant projects example in Canada is the Drake Landing Solar Community (DLSC) [14] in 2007 which is supplying $90 \%$ of heat demand and $60 \%$ hot water demand in total 52 numbers of single house detached family. Eight hundred solar flat plate panels $(2.45 \mathrm{~m} \times 1.18 \mathrm{~m})$ are producing 1.5 MW of thermal power and supply heat to the district heating system. The panels are connected 
with an underground pipe that carries the heated energy to the community's thermal energy storage system.

The storage system is BTES types, and it has 144 holes, each stretching depth is 37 meters, 35 meters diameters. In DLSC, every house is a typical Canadian single-family detached house with 1492 to 1664 square feet in size, which is almost similar to [14]. A large energy-saving building $(1,68,000$ square feet) recently constructed by East Port Properties, Canada before 25 years in St. John's, Newfoundland. It is the first building in Newfoundland, which is using seawater tides for space heating and cooling with 50\% energy efficiency[15]. To meet government GHG reduction targets the Newfoundland provincial government are increasing the renewable energy-based power plants and are reducing the fossil fuel-based power plants. The Newfoundland government is also focusing on green building energy projects like solar-based thermal energy, storage system design, net-zero energy building, energy efficiency, and many more relating to green energy production [16]. The $\mathrm{K}$ \& P contracting Ltd. first successfully built up a net-zero energy home in St. John's, Newfoundland on 2013 [17]. They installed the necessary solar panel to the rooftop and a wind turbine. During the sunny day, solar energy is collected, and during the windy day, the energy comes from wind, and we can store both energies in the thermal energy storage tank.

Ronald Brakels mentioned that the sun flux company in Australia proposed the newly designed off-grid PV water heat controller that can be manually and automatically controlled from PV or to the grid. Its efficiency is excellent, but this is not suitable for a bulk amount of electricity generation and heating element. Its rating is near to $4.00 \mathrm{~kW}$, which is capable of raising the temperature to $3.4^{\circ} \mathrm{C}$ per hour in a 250-liter water tank [18].

Fudholi at al.[19] analyzed the performance of photovoltaic (PV) and photovoltaic thermal (PVT) and compared the cost, efficiency, and output. He designed both systems for water heating purposes and found that the total yearly output power generation is almost same with PV and PVT systems. However, the problem is that the PVT system cost is much higher than the PV based systems.

In this work, a residential house has been selected and analyzed its annual consumption, designed the required solar thermal collector and water tank, and designed the required PV systems as well as control systems. Finally, the performance and installation cost has been compared.

\section{Data Collection and Analysis}

\subsection{Weather Analysis}

The tested house location is 5, Blue River Place, St. John's, NL, Canada. Based on the PolySun software analysis, the minimum wind speed for power generation is $2 \mathrm{~m} / \mathrm{s}$, and the maximum value is $10 \mathrm{~m} / \mathrm{s}$. At St. John's, NL the average wind speed is $6.6 \mathrm{~m} / \mathrm{s}$ that is suitable for electricity generation. The average daily solar radiation is $3.06 \mathrm{kWh}$ per $\mathrm{m}^{2}$ per day, which is enough to generate heat or electricity. Based on the HOT2000 software, in the selected house location, it is found that the annual sum of global irradiation is $1130 \mathrm{kWh} / \mathrm{m}^{2}$ and the annual sum of diffuse irradiation is $611 \mathrm{kWh} / \mathrm{m}^{2}$. The average minimum and maximum temperature at St. John's NL are the $1^{\circ} \mathrm{C}$ and $9^{\circ} \mathrm{C}$, respectively, as shown in Figure. 1. 


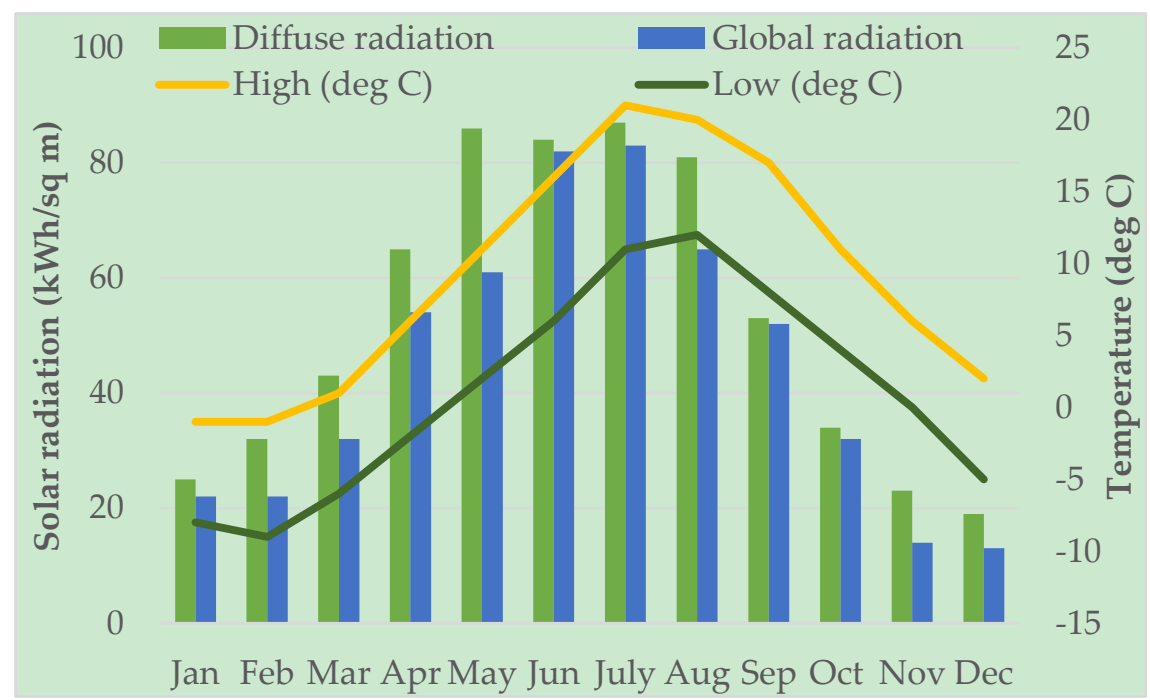

Figure 1. Yearly solar radiation and temperature data

\subsection{House Analysis}

The considered house is a typical single-family house in Canada, and the details of this house described in Table 1. In the tested house, the hot water supplied by a boiler and space heating is provided by the grid electricity that is the most common scenario of all Newfoundland single-family houses. Thus the vast grid electricity is required, and consumers are paying a large amount of electric bill every year.

Table 1. The tested single-family house details

\begin{tabular}{ll}
\hline House Particulars & Values \\
\hline Latitude & 47.6 \\
Longitude & -52.7 \\
Facility full size $(13.7 \mathrm{~m} \times 9.144 \mathrm{~m})$ & $125.27 \mathrm{~m}^{2}$ \\
Annual energy demand (space heating \& domestic hot water) & $153.56 \mathrm{KWh} / \mathrm{m}^{2}$ \\
Hot water temperature & $50^{\circ} \mathrm{C}$ \\
Space heating setpoint temperature & $24^{\circ} \mathrm{C}$ \\
Annual electricity demand (Based on NL power) & $19007 \mathrm{kWh}$ \\
Annual electricity demand (BEopt. analysis) & $19511 \mathrm{kWh}$ \\
\hline
\end{tabular}

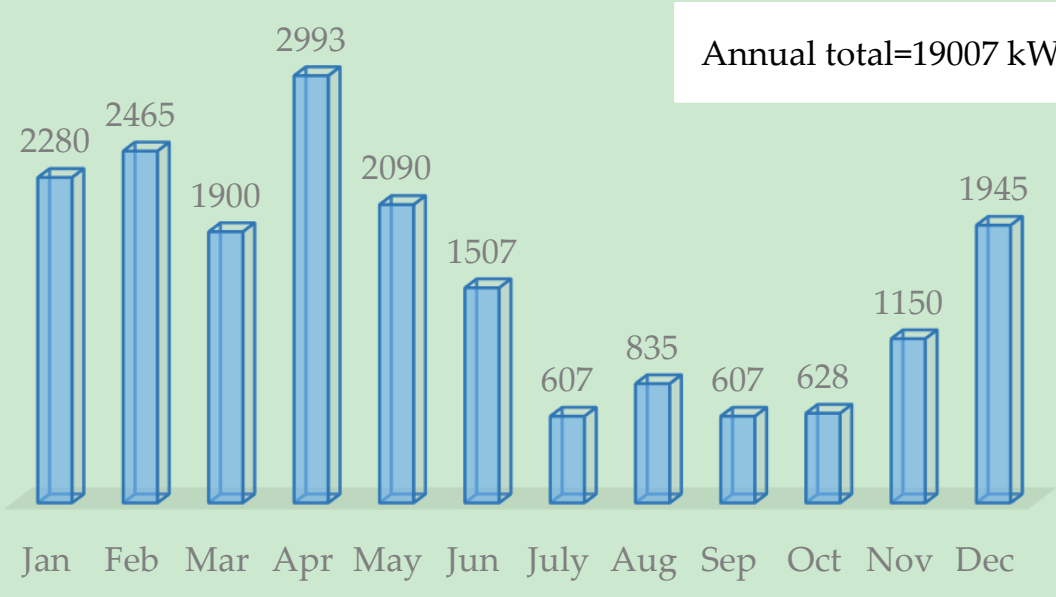

Figure 2. The total actual electricity consumption (kWh), 2017. 


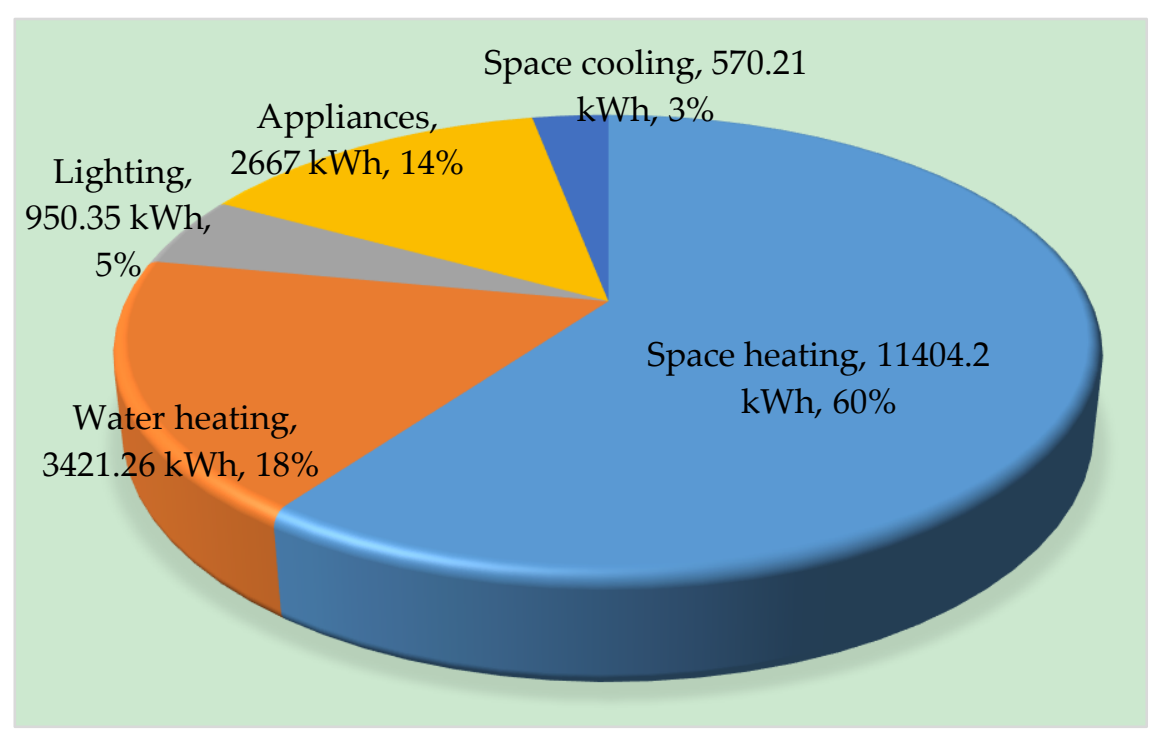

Figure 3. The actual electricity consumption distribution [20]

Based on NL power annual bill summary, the considered house present annual demand is around $19007 \mathrm{kWh}$ of electricity for space heating, DHW and other electrical appliances as shown in Figure. 2 and the distribution of this consumption shown in Figure. 3 based on where it found that the majority of electricity consumed for space heating and DHW.

\subsubsection{House Analysis in BEopt Software}

This house again was analyzed by using the BEopt. Software. The selected house is shown in Figure.

4. The selected house annual energy demand determination steps are given below:

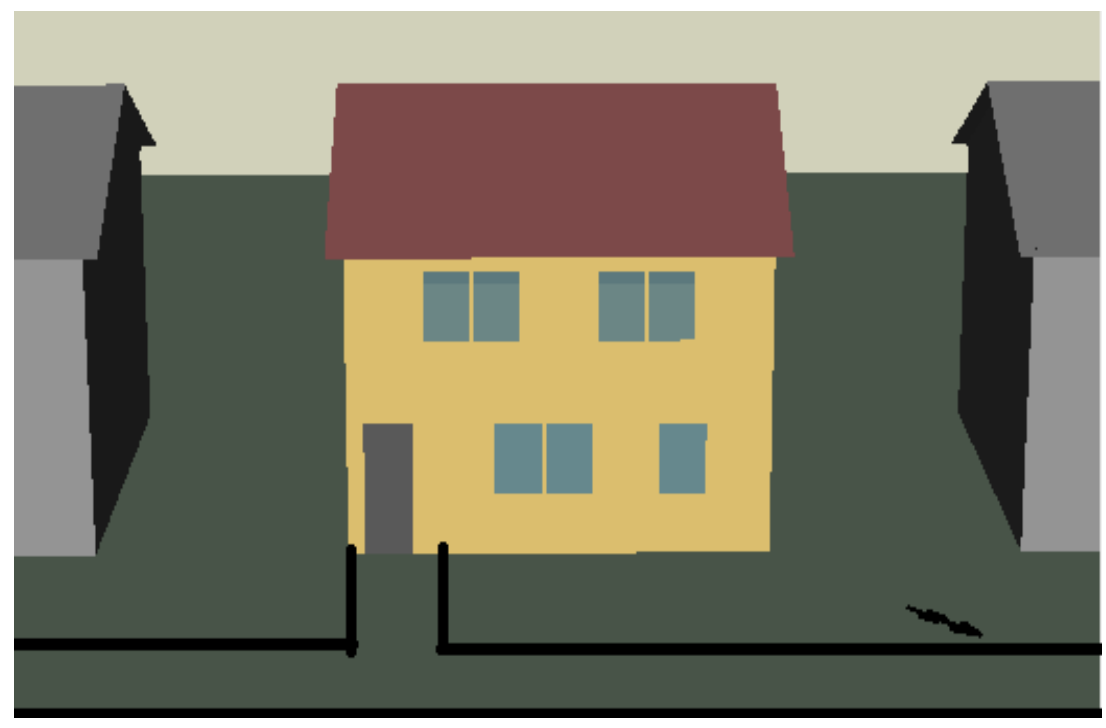

Figure 4. The geometry and the schematic view of the selected house

The house parameters are described in Table 2. 


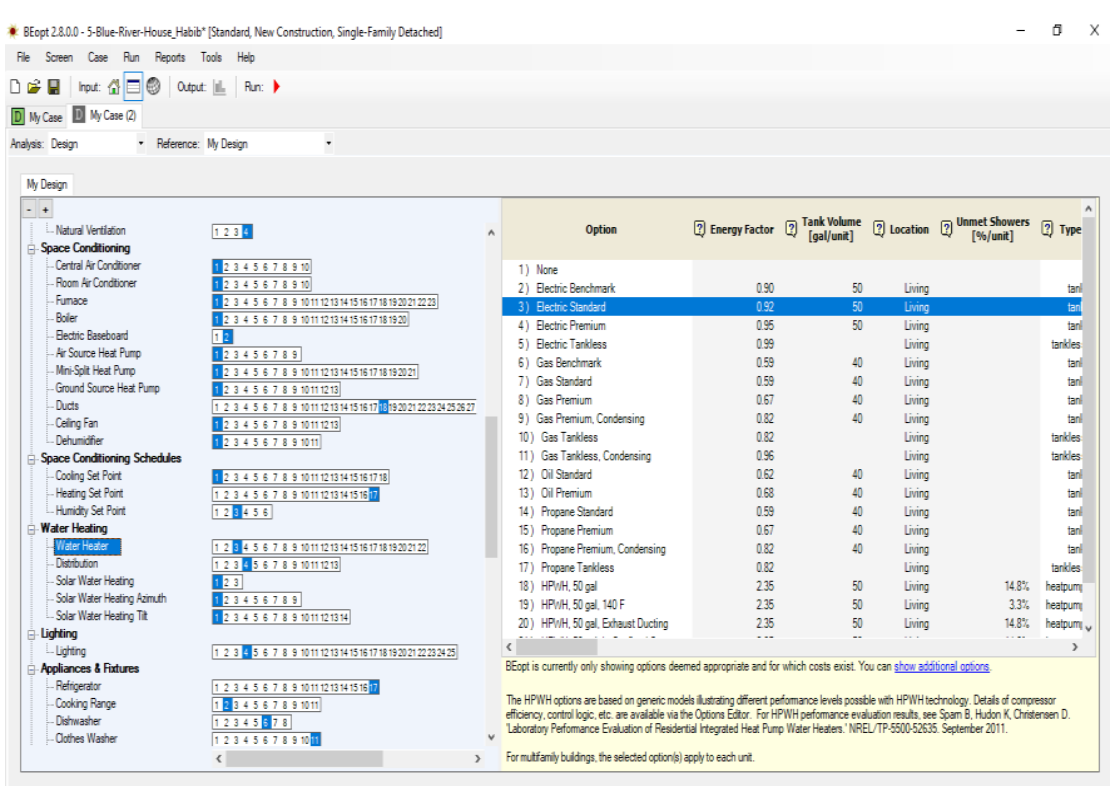

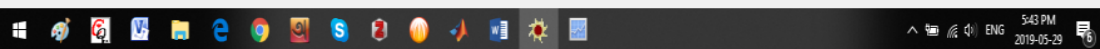

Figure 5. The input parameters of the selected house.

Table 2. The complete summary of all input parameters

\begin{tabular}{|c|c|c|}
\hline SL. No & Options screen & The input of a house \\
\hline \multirow[t]{3}{*}{1} & Building & \\
\hline & Orientation & Northwest \\
\hline & Neighbors & Left/Right at $4.57 \mathrm{~m}$. \\
\hline \multirow[t]{4}{*}{2} & Wall & \\
\hline & Wood stud & R- 15 Fiberglass Batt, $2 * 4,16$ in o.c \\
\hline & Wall sheathing & OSB \\
\hline & Exterior finish & Vinyl, light \\
\hline \multirow[t]{3}{*}{3} & Ceilings/Roofs & \\
\hline & Unfinished attic & Ceiling R-38 Fiberglass, Vented \\
\hline & Roof material & Asphalt Shingles, Medium \\
\hline \multirow[t]{4}{*}{4} & Foundation/Floors & \\
\hline & Finished basement & Whole wall R-13 Fiberglass Batt, $2 * 4,16$ in o.c \\
\hline & Interzonal floor & Uninsulated \\
\hline & Carpet & $0 \%$ Carpet, $\mathrm{R}$ value is 2.08 \\
\hline \multirow[t]{5}{*}{5} & Thermal mass & \\
\hline & Floor mass & Wood Surface \\
\hline & Exterior wall mass & $1 / 2$ in. Drywall \\
\hline & Partition wall mass & $1 / 2$ in. Drywall \\
\hline & Ceiling wall mass & $1 / 2$ in. Drywall \\
\hline \multirow[t]{6}{*}{6} & Windows \& Doors & \\
\hline & Window areas & $16.44^{\mathrm{m} 2}$ total (12 numbers) \\
\hline & Windows & Clear, Double, Non-metal, Air, H gain \\
\hline & Door Area & $1.85 \mathrm{~m}^{2}$ \\
\hline & Doors & Wood \\
\hline & Eaves & $0.3 \mathrm{~m}$. \\
\hline \multirow[t]{3}{*}{7} & Airflow & \\
\hline & Air leakage & $4 \mathrm{ACH} 50$ \\
\hline & Mechanical ventilation & 2010, HRV, $70 \%$ \\
\hline
\end{tabular}




\begin{tabular}{|c|c|c|}
\hline & Natural Ventilation & Cooling months only, 7 days/week \\
\hline \multirow[t]{3}{*}{8} & Space conditioning & \\
\hline & Electric baseboard & $100 \%$ Efficiency \\
\hline & Ducts & $7.5 \%$ Leakage, Uninsulated \\
\hline \multirow[t]{2}{*}{9} & Space conditioning & \\
\hline & Heating setpoint & $60 \mathrm{~F}$ (My Test) \\
\hline \multirow[t]{3}{*}{10} & Water Heating & \\
\hline & Water heater & Electric Standard \\
\hline & Distribution & Uninsulated, Home Run, PEX \\
\hline \multirow[t]{2}{*}{11} & Lighting & \\
\hline & Lighting & 34\% CFL Hardwired, $34 \%$ CFL plugin \\
\hline \multirow[t]{7}{*}{12} & Appliances and fixtures & \\
\hline & Refrigerator & Top freezer, $\mathrm{EF}=21.9$ \\
\hline & Cooking range & Electric \\
\hline & Dishwasher & 219 Rated Kwh, $80 \%$ usages \\
\hline & Clothes washer & Energy start, Cold water only \\
\hline & Clothes dryer & Electric \\
\hline & Hot water fixtures & A new input has been inserted (My Test) \\
\hline \multirow[t]{2}{*}{13} & Miscellaneous & \\
\hline & Plug Loads & 1.0 \\
\hline
\end{tabular}

All input parameters have been selected carefully based on the existing materials and then clicked on the run button. The simulation was running for 3 minutes, and then the following output has been found, as shown in Figure. 6 7.

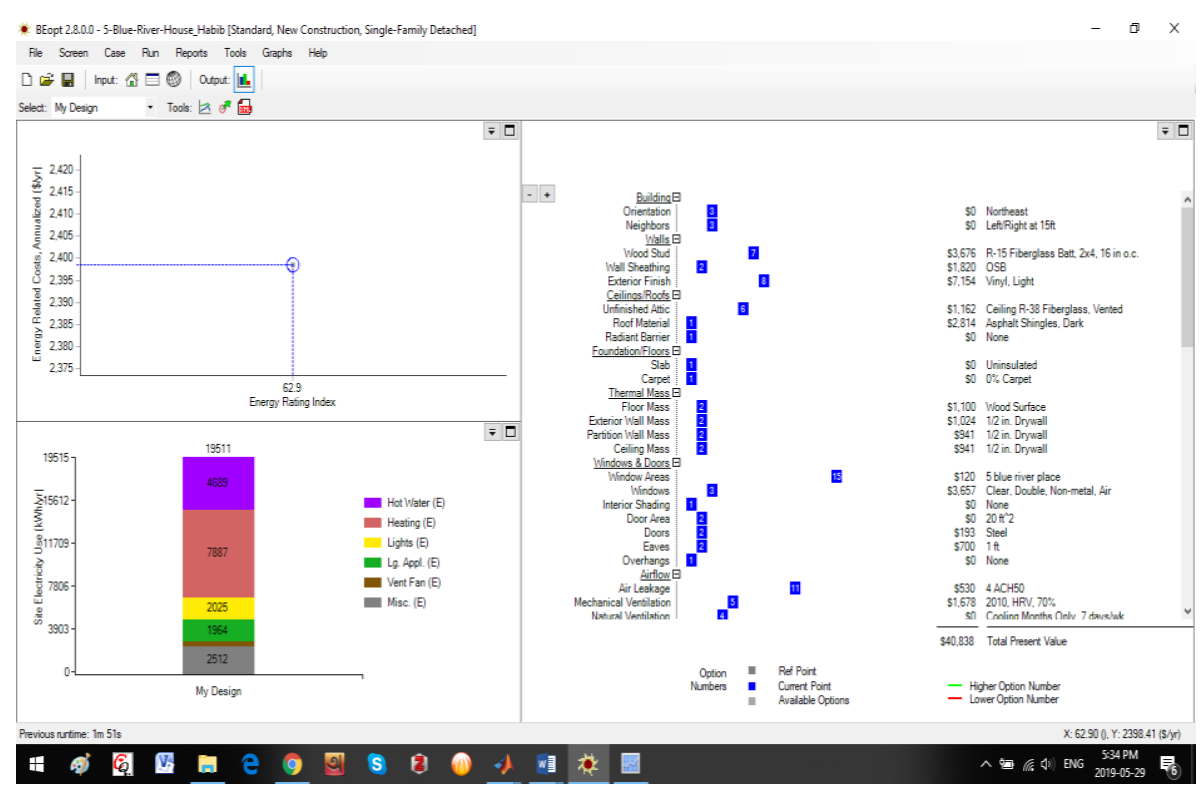

Figure. 6 The overview of the simulated result. 


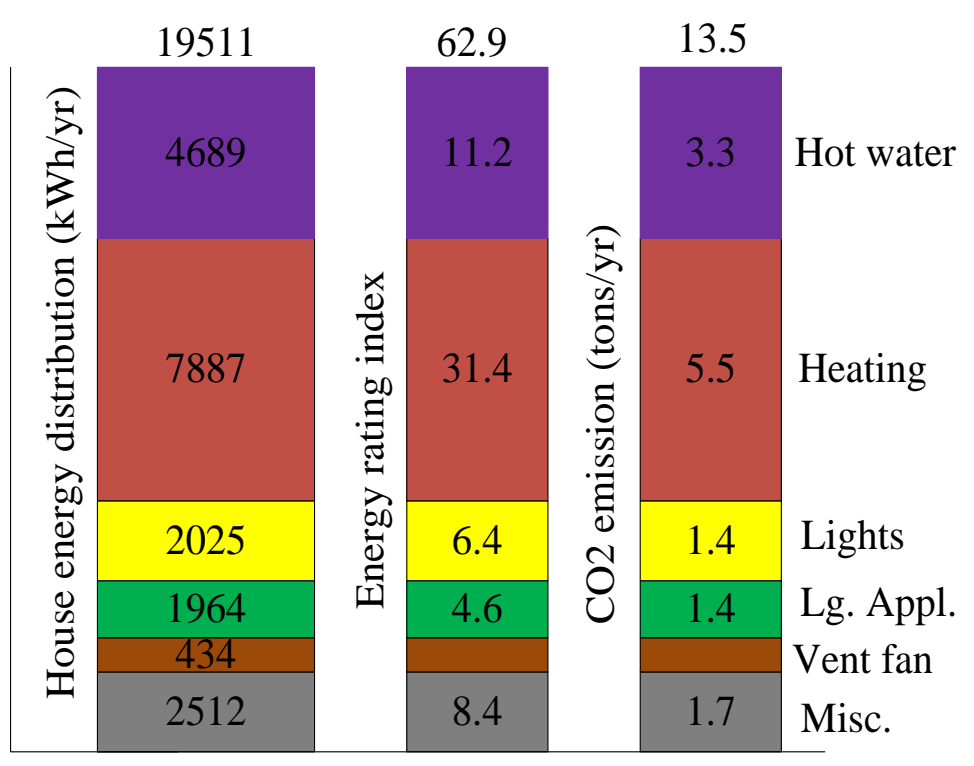

Figure 7. The tested house standard annual energy demand.

It is found that the actual energy consumption in the house in Figure. 2 is almost similar to the electrical and thermal consumption of the house, as shown in Figure. 7.

\section{Solar Collector Based Systems}

A solar thermal collector and the heat pump added included with the larger size water tank. As solar energy is always variable, so when it will not be available, then the heat pump will act as an auxiliary burner that will keep the water temperature at the desired value. The modified space heating and hot water supply diagram in a single-family house given in Figure. 8.

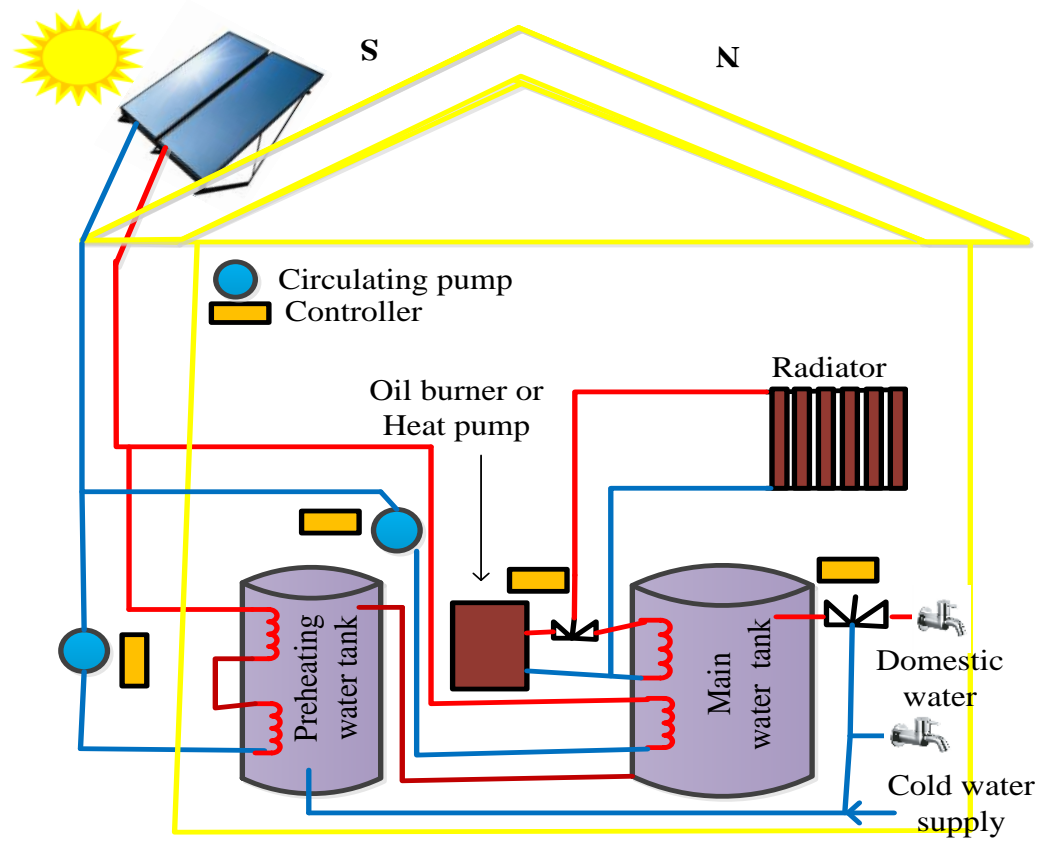

Figure 8. The proposed model for the tested house. 
A solar collector is the primary source of renewable energy in this work. In this research, the water medium considered in the tanks. The stored hot water carried to the radiator for space heating purposes and to the hot water taps (kitchen, bathrooms). To control the circulating pumps are mandatory for water flow. For enhancing heat transfer, proper design is essential. The example site is a single-family house. The DHW distribution scenario in 24 hours, as mentioned in Figure. 9. The design calculation for hot water heating given below [21]:

Beds, $\mathrm{B}=02$ numbers

Occupation, $\mathrm{O}=200 \%$ (considered, four people are living)

Per person hot water demand, DHW= 20 liter/day

Hot water demand in kitchen, $\mathrm{HWD}_{\mathrm{k}}=30$ liter/day

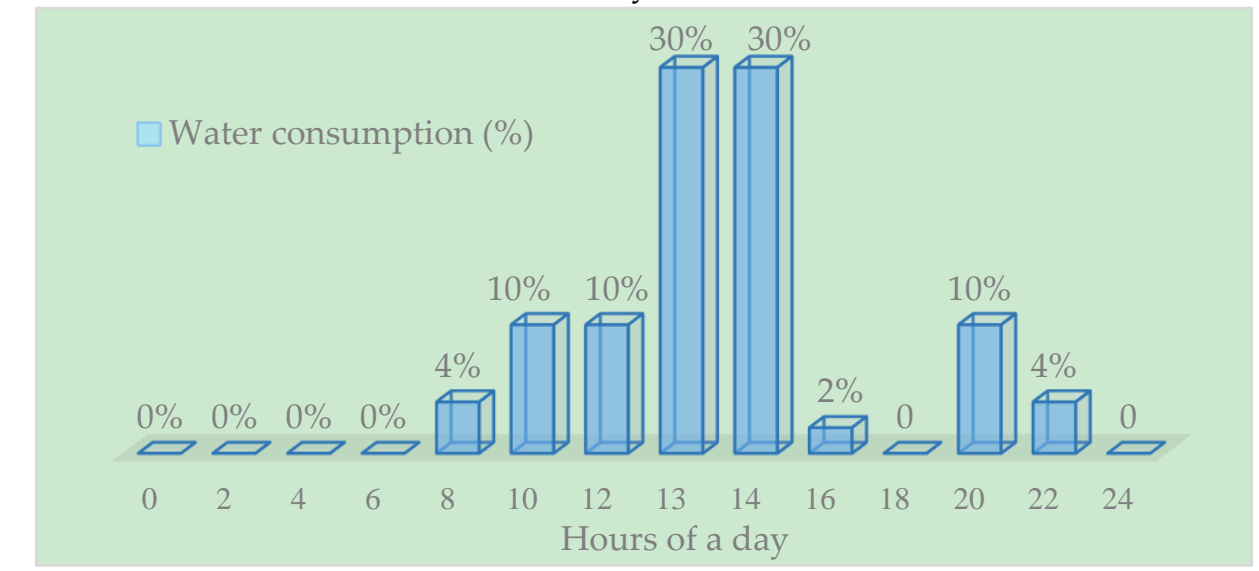

Figure 9. The daily water consumption scenario in the tested house

Coldwater temperature $=10^{\circ} \mathrm{C}$.

Storage hot water temperature $=55^{\circ} \mathrm{C}$.

Average solar radiation for high solar fractions=3.06 (Kwh/sq. m/d).

Storage volume,

$$
\begin{aligned}
V_{S T} & =\left[(B \times O \times D H W)+H W D_{K}\right] \times 1.2 \\
& =[(02 \times 02 \times 20)+30] \times 1.2 \\
& =132 \text { liter }=0.132 \mathrm{~m}^{3}
\end{aligned}
$$

Where B is the number of bedrooms in the house.

$\mathrm{O}=$ Percentage of occupation, number of people on average.

$\mathrm{DHW}=$ Hot water use by per person in the bathroom.

$\mathrm{DHW}_{\mathrm{k}}=$ Hot water use by per person in the kitchen.

Energy demand for hot water,

$$
\begin{aligned}
Q_{S} & =V_{S T} \times C_{p} \times \Delta T \\
& =0.132 \times 1.16 \times 45=6.89 \mathrm{kWh} / \text { day } .
\end{aligned}
$$

Where, $C_{p}$ is the heat capacity of water in $\mathrm{kWh} / \mathrm{m}^{3} \mathrm{~K}$.

$\Delta T$ is the temperature difference between hot and cold water.

$\Delta T$ is the temperature difference between hot and cold water.

By using HOT2000 software, the calculated global solar radiation at AM 1.5 for St. John's, NL, Canada and it is $S_{r}=2.9 \mathrm{kWh} /$ day. $\mathrm{m}^{2}$

Collector yield,

$$
C_{Y}=S_{R} \times \eta_{K} \times \eta_{s y s}
$$


$=2.9 \times 0.6 \times 0.8=1.392 \mathrm{kWh} / \mathrm{m}^{2}$.

Where $\eta_{K}$ is the collector efficiency and $\eta_{s y s}$ is the system efficiency such as storage, piping. If $100 \%$ solar fraction, the maximum value considered then,

Collector array, $C_{A}=\frac{Q}{C_{Y}}=\frac{6.89 \mathrm{kWh}}{1.392 \frac{\mathrm{kWh}}{\mathrm{s.m}}}=4.95 \mathrm{~m}^{2}$

The design calculation for space heating given below:

A standard flat plate collector can produce $9085.23 \mathrm{~kW} / \mathrm{m}^{2} /$ day [22], and the daily requirement is 202.7 $\mathrm{kW} / \mathrm{m}^{2} /$ day

The required number of collectors $=\frac{\text { Daily requirement }}{\text { Collecotor output }}=0.0223\left(\mathrm{~m}^{2} / \mathrm{day}\right)$

The total number of collectors $=0.02231\left(\mathrm{~m}^{2} /\right.$ day $) \times 125.27 \mathrm{~m}^{2}=2.7$ per day.

The surface area of collector array $=$ No of collectors $\times$ size of each collector in $\mathrm{m}^{2}$

$$
=2.7 \times 1.9 \mathrm{~m}^{2}=5.13 \mathrm{~m}^{2}
$$

AE-21 model solar collector dimension is considered

Total collector area for space heating and DHW=10.08 $\mathrm{m}^{2} \cong 10 \mathrm{~m}^{2}$ (eq. 4 and eq. 6).

The collector should be facing the south at an angle of $47^{\circ}$. As the selected house is on the northern side of the equator, so the collector should be placed in a south-facing [20].

\subsection{Selection of Water Tanks and Burners}

In the tested house, the existing tank or boiler size is smaller because the only DHW supplied by using this tank. The conventional electric heater is using to supply space heating. The tank water is heating by using grid electricity. The preheating water tanks designed in section V (A) which is 132 liter, and 200-liter water tank (stainless) considered as the main tank by optimized, as shown in Figure 8 for both models. The solar energy is intermittent, so for maintaining the fixed temperature auxiliary burner is necessary. There are different types of auxiliary burner available in literature such as a gas burner, heat pump, oil burner, Siemens, hydraulic, air inverter, air combo. Before selection, the consideration of input and output power of each burner is essential. Among them, the oil burner and the heat pump is popular in NL area. The oil burner efficiency is less compared to the heat pump. The performance of both systems compared in Table 4. The heat pump power consumption considered as a load of the designed house.

\subsection{Installation cost analysis}

The setup cost distribution for the solar collector and energy storage system described in Figure. 10. 


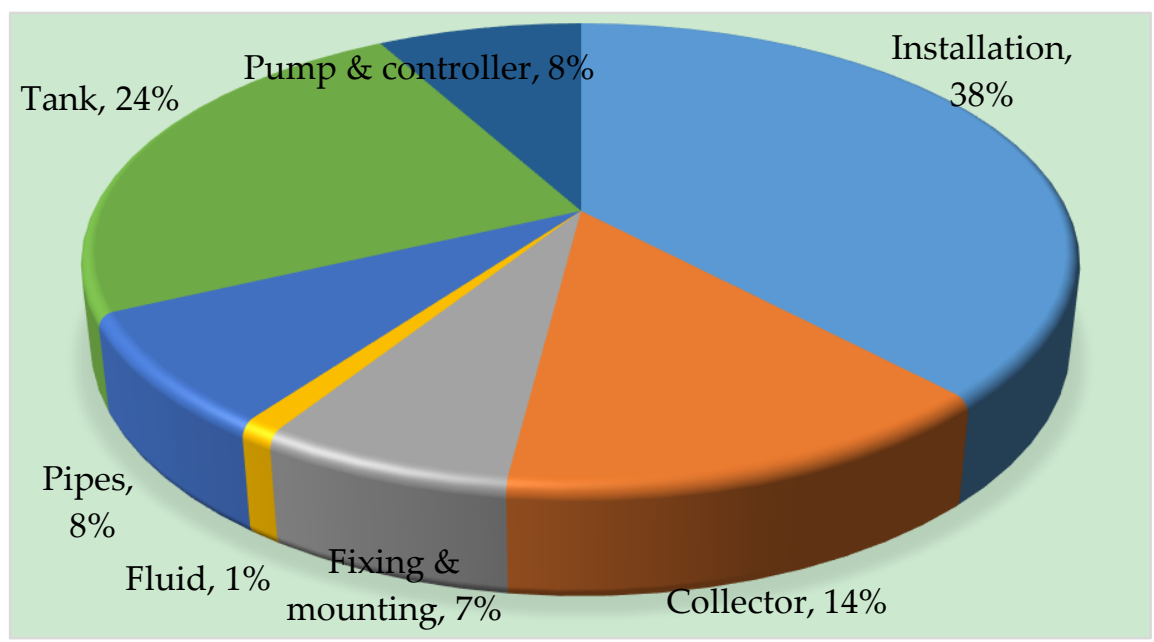

Figure 10. Installation cost distribution by section [23]

The calculation has been done based on the above design and the latest market price in Amazon.ca

Table 3. The cost summary of collector based systems based on Amazon.ca.

\begin{tabular}{ll}
\multicolumn{1}{c}{ Descriptions } & \multicolumn{1}{c}{ Sizing and prices } \\
\hline The selected collector area (each) & $68 \times 48 \times 60$ inches $=2.1 \mathrm{~m}^{2}$. \\
The total area of all solar collector & $2.1 \times 5=10.5 \mathrm{~m}^{2}$. \\
Tank size (need two tanks for that purpose) & $332 \mathrm{Liter}$ \\
Solar collector cost & $5 \times 3000=30000$ CAD \\
Installation costs & $30000 \times 0.34=10200$ CAD \\
Tank cost & $2000 \times 2=4000$ CAD \\
Pipes cost & 2400 CAD \\
Pumps and controllers cost & 2400 CAD \\
Others cost & 2400 CAD \\
Total investment cost & 51,400 CAD. \\
\hline
\end{tabular}

\subsection{Simulation Result}

The modified single-family house, as shown in Figure. 8 has been designed and simulated in professional PolySun designer environment. In the simulation, there are two models as considered like model 1: a general solar collector, an oil burner for heat sources and in model 2: premium quality collector, heat pump for heat sources. Rest of the parts of the system remains the same for both cases such as tank size, types, house energy demand (DHW and space heating).

The simulation has been done carefully for every month of a year. It found that the model 2 solar fraction and collector output is always higher compared to model 1. The collector output is available around the year, as shown in Figure. 11. 


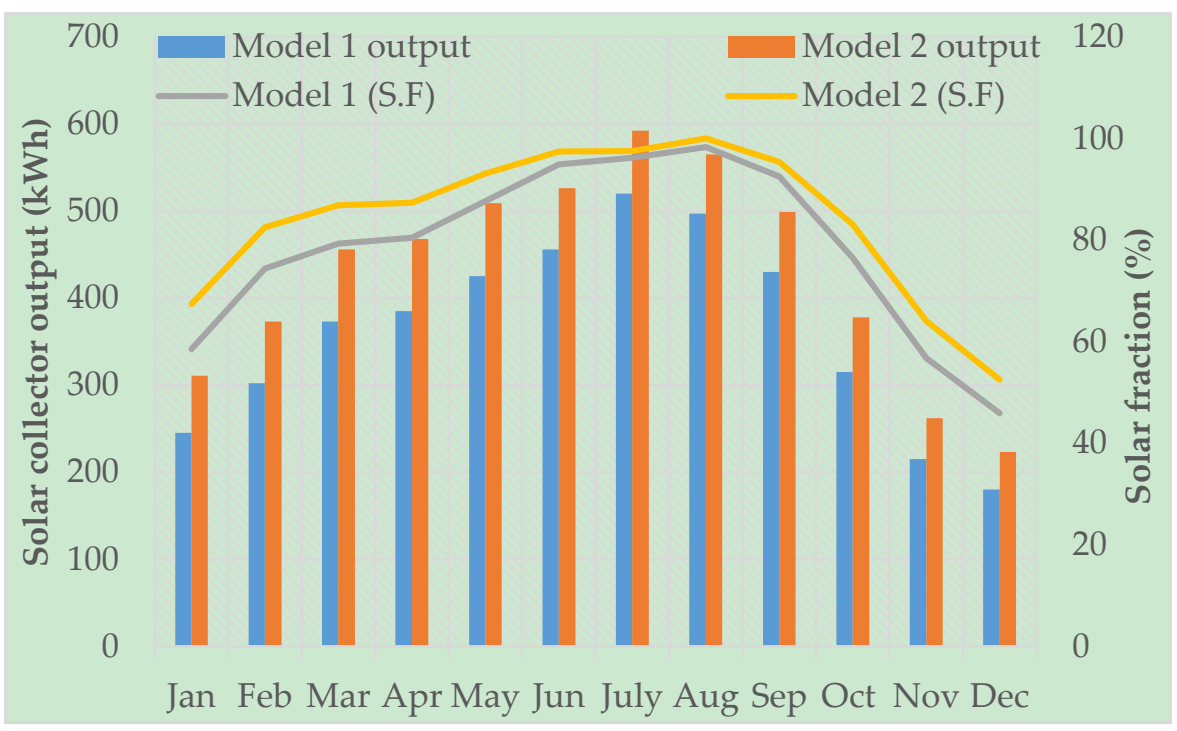

Figure 11. Solar collector and fraction comparison.

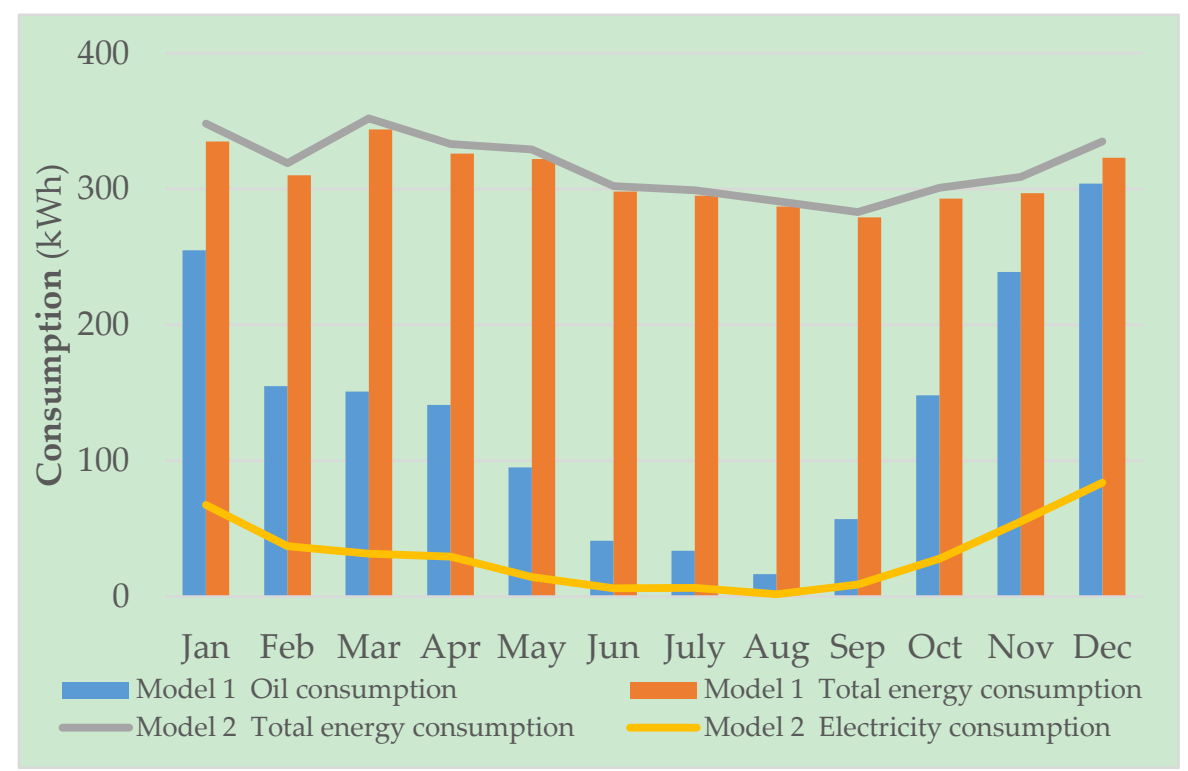

Figure 12. Burners and hot water energy demand

The total system energy consumption with a heat pump and with the oil burner are almost the same because this is the total energy consumption of the systems. As the oil burner input is furnace oil with $95 \%$ efficiency and the consumption is higher than the electricity consumption in the heat pump. The average efficiency of the heat pump is around $300 \%$ to $500 \%$. Usually, from Jun to Aug is the hottest months in Newfoundland, so the overall consumption is lower than the other months, as shown in Figure. 12. Here the total energy consumption means electrical and thermal energy. The efficiency of the oil burner is less compared to the heat pump, that is why to do the same purpose, the consumption is more than the heat pump. 


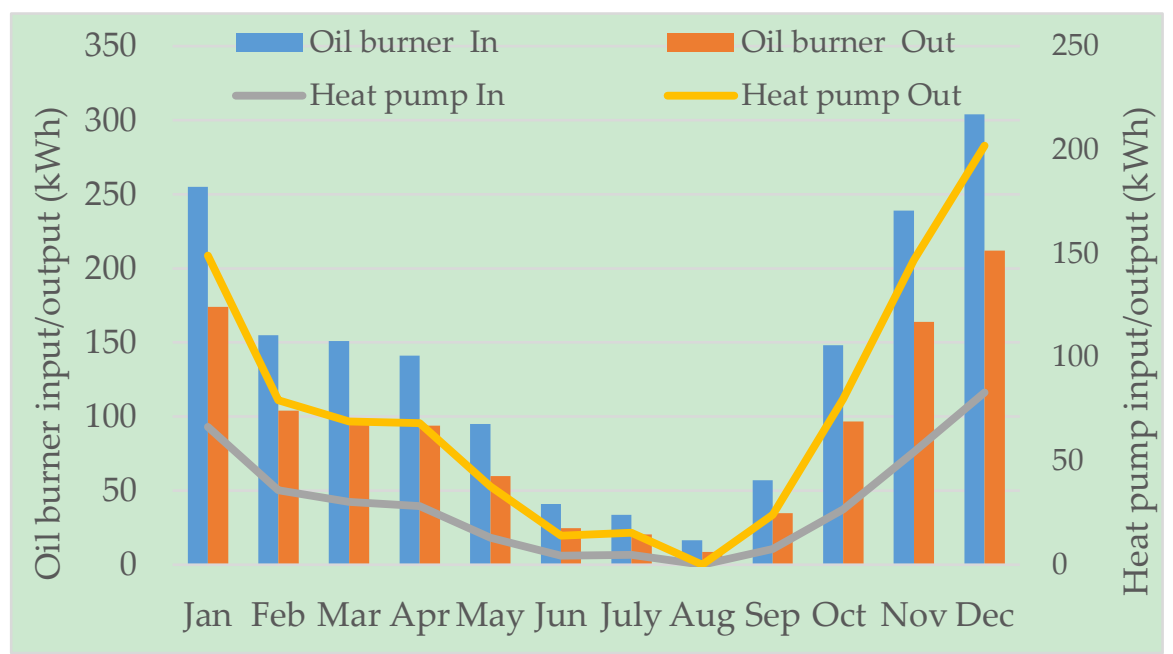

Figure 13. Burner's efficiency comparison.

The efficiency of an oil burner and heat pump compared in Figure. 13. It found that the output is much higher to input for heat pump (model 2). The COP is 3.33 for the heat pump but based on the oil burner (model 1) efficiency curve, and it is not suitable for the application. The designed system is correct, and energy demand is satisfied, as shown in Figure. 12.

The existing house can modify now to the energy-efficient house in two possible ways such as model 1 and model 2. The performance of both systems compared in Table 4. In NL, Canada the electricity price is $0.12 \mathrm{CAD} / \mathrm{kWh}$ that considered for electric bill calculation. Usually, one liter of furnace oil price is $0.82 \mathrm{CAD}$, which is also equivalent to $10.27 \mathrm{kWh}$ of energy.

Table 4. Performance comparison of two models

\begin{tabular}{|c|c|c|c|c|}
\hline Basic sections & Particulars & $\begin{array}{l}\text { Existing/ } \\
\text { reference } \\
\text { system }\end{array}$ & $\begin{array}{l}\text { Model } 1 \\
\text { Burner) }\end{array}$ & $\begin{array}{l}\text { Model } 2 \text { (Heat } \\
\text { pump) }\end{array}$ \\
\hline \multirow{4}{*}{ Solar collector } & Type & $\mathrm{N} / \mathrm{A}$ & Flat plate & Flat plate \\
\hline & $\begin{array}{l}\text { Number of } \\
\text { collectors }\end{array}$ & N/A & 05 (No tracking) & 05 (No tracking) \\
\hline & Total gross area & $\mathrm{N} / \mathrm{A}$ & $10 \mathrm{~m}^{2}$ & $10 \mathrm{~m}^{2}$ \\
\hline & Annual Output & $\mathrm{N} / \mathrm{A}$ & $4345 \mathrm{kWh}$ & $5161 \mathrm{kWh}$ \\
\hline \multirow[b]{2}{*}{ Storage tank } & Volume & 181 Liter & $(132+200)$ Liter & $(132+200)$ Liter \\
\hline & Functions & DHW only & $\begin{array}{c}\text { DHW and space } \\
\text { heating }\end{array}$ & $\begin{array}{c}\text { DHW and space } \\
\text { heating }\end{array}$ \\
\hline \multirow{2}{*}{$\begin{array}{l}\text { Auxiliary } \\
\text { burner }\end{array}$} & Type, capacity & $4 \mathrm{~kW}$ & Oil burner $(3 \mathrm{~kW})$ & Heat pump $(3 \mathrm{~kW})$ \\
\hline & $\begin{array}{c}\text { Energy } \\
\text { input/output }\end{array}$ & Same & 1635/1091 kWh & 354/882 kWh \\
\hline $\begin{array}{c}\text { Energy } \\
\text { demand/ } \\
\text { shortage }\end{array}$ & $\begin{array}{c}\text { DHW and space } \\
\text { heating }\end{array}$ & $\begin{array}{c}14825.5 \\
\text { kWh }\end{array}$ & $\begin{array}{c}9389.5 \text { kWh }+159.2 \\
\text { L Oil }\end{array}$ & $8320.5 \mathrm{kWh}$ \\
\hline \multirow{2}{*}{$\begin{array}{c}\text { Annual } \\
\text { consumer bill }\end{array}$} & $\begin{array}{c}\text { DHW and space } \\
\text { heating }\end{array}$ & 1690 CAD & 1201 CAD & 998.46 CAD \\
\hline & Savings & No & $29 \%$ & $43.77 \%$ \\
\hline
\end{tabular}


Annual output (collector \& heat pump system) $=5161 \mathrm{kWh}$ (without tracking) Annual saving $=2090.77 \times 0.387=809.127$ CAD.

\subsection{Performance Analysis}

In this research, it shown that if a Newfoundland detached house can modify by using proposed model 2 (with heat pump) for heating and DHW supply, then the grid energy demand will be mitigated by using renewable energy and people will see a considerable reduction in electricity bill every month. Besides that, $\mathrm{CO}_{2}$ emission will reduce significantly. During the peak time usually, the electricity demand is high if the proposed system (model 2) will apply, then grid overloading will not occur in the future. People need to invest money for the first time as the additional equipment installation cost, and it will return within a few years from energy saving. The proposed system (model 2) is practically applicable, profitable, and reliable. This research can be further modified by using the latest designed collector with tracking, using sessional energy storage system and the design of the required control system.

\section{Solar Photovoltaic Based System}

The central systems in Figure. 8 is considered again with the solar PV module instead of solar thermal collector, and the design steps are given below [24]:

\subsection{Sizing PV for Water Heating}

Required load for water heating $=6.89 \mathrm{kWh} /$ day (standard two rooms for 4 people)

Total PV panels energy needed $=6.89 \mathrm{kWh} /$ day $\times 1.3=8.957 \mathrm{kWh} /$ day.

Total Wp of PV panel capacity needed $=8957 \mathrm{Wh} /$ day $/ 3.4=2634 \mathrm{Wp}$.

Number of PV module $=2634 \mathrm{Wp} / 150 \mathrm{~W}=17.56$ modules $\cong 18$ modules.

The area of PV panel $=0.93 \times 0.675 \mathrm{~m}^{2}=0.6277 \mathrm{~m}^{2} /$ per panel

The total area of PV panel $=0.6277 \mathrm{~m}^{2} \times 18=11.3 \mathrm{~m}^{2}$

\subsection{Sizing for Space Heating}

Required load for space heating $=20.27 \mathrm{kWh} /$ day [standard two rooms with 4 people]

Total PV panels energy needed $=20.27 \mathrm{kWh} /$ day $\times 1.3=26.35 \mathrm{kWh} /$ day.

Total Wp of PV panel capacity needed $=26350 \mathrm{Wh} /$ day $/ 3.4=7750 \mathrm{Wp}$.

Number of PV module $=7750 \mathrm{Wp} / 150 \mathrm{~W}=51.66$ modules $\cong 52$ modules.

The area of PV panel $=0.93 \times 0.675 \mathrm{~m}^{2}=0.6277 \mathrm{~m}^{2} /$ per panel

The total area of PV panel $=0.6277 \mathrm{~m}^{2} \times 52=32.64 \mathrm{~m}^{2}$

The total number of a solar panel for water and space heating is 70 numbers, which are equal to 43.94 $\mathrm{m}^{2}$.

\subsection{Sizing of Inverter and the MPPT}

For safety, the inverter should be considered $20-25 \%$ bigger size. For this project, the inverter size is $12000 \mathrm{~W}$. The detail specification of the PV module described in section 5.4, and the detail specification of the electric water heating tank. The maximum power point tracking (MPPT) is optional in this research. If anybody wants to supply the excess electricity to the residential load or appliances, then it will be necessary. 


\subsection{Specifications of Selected PV Panel}

There are many companies that manufacturing PV module, we picked one, and the detail descriptions of the selected $150 \mathrm{~W}$ PV Polycrystalline module is given below: Item Size: $930 \times 675 \times 3 \mathrm{~mm}$, maximum power (Pmax): 150W, the voltage at Pmax (Vmp): 18.2V, current at Pmax (Imp): 8.34A, open-circuit voltage (Voc): 21.6V, short-circuit current (Isc): 9.17A [25].

\subsection{Control and Monitoring Systems}

The description of each PV module has been describing in section 3.5. The complete system is shown in Figure 14, and the controller operating principle is described in Figure 15. During the day time, when the sunshine is available, the tree position switch transfers the AC power to the water tank. The temperature of the water reaches the desired temperature $\left(50^{\circ} \mathrm{C}\right)$ within two hours. The sensors always monitor the water temperature, when reaching the tree position switch transfer the power to the room heater-1 and room heater-2. After consumption of some hot water, new cold water comes into the tank; if the temperature is below the set temperature, the three-position switch again connects to the tank. In this way, the water tank temperature always maintains the set temperature. During the night time, when the solar energy is not available, then it is difficult to maintain the set temperature, then based on the temperature sensor reading, auxiliary heater coil supply heat from the electric grid to the water to maintain the water temperature based on the set temperature. When the water level is right then the valve two is not taking cold water, when the level goes lower then valve two open until the tank fills up. The controller will do everything, as shown in Figure. 14.

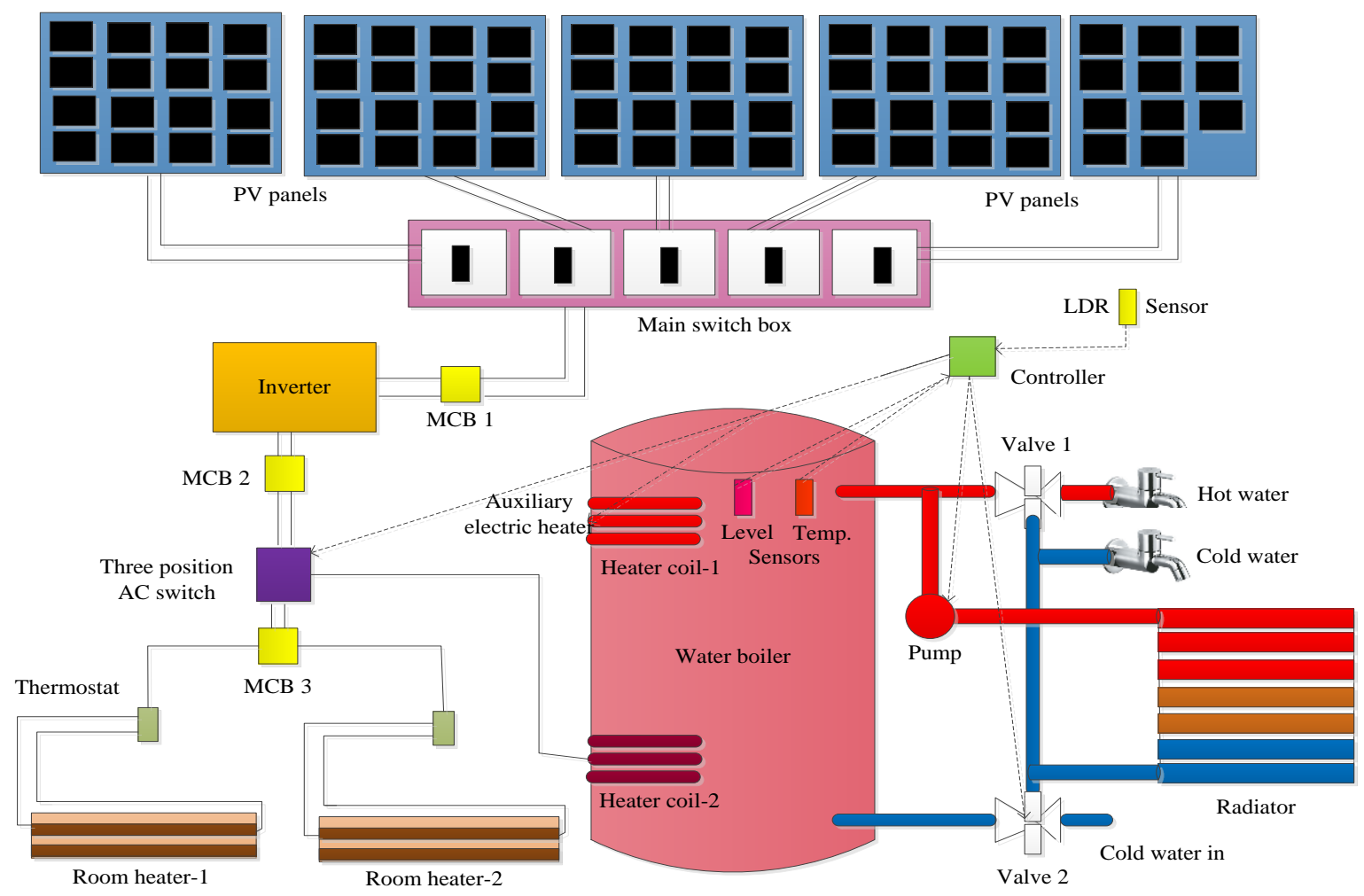

Figure 14. Solar PV based residential water heating and space heating system 


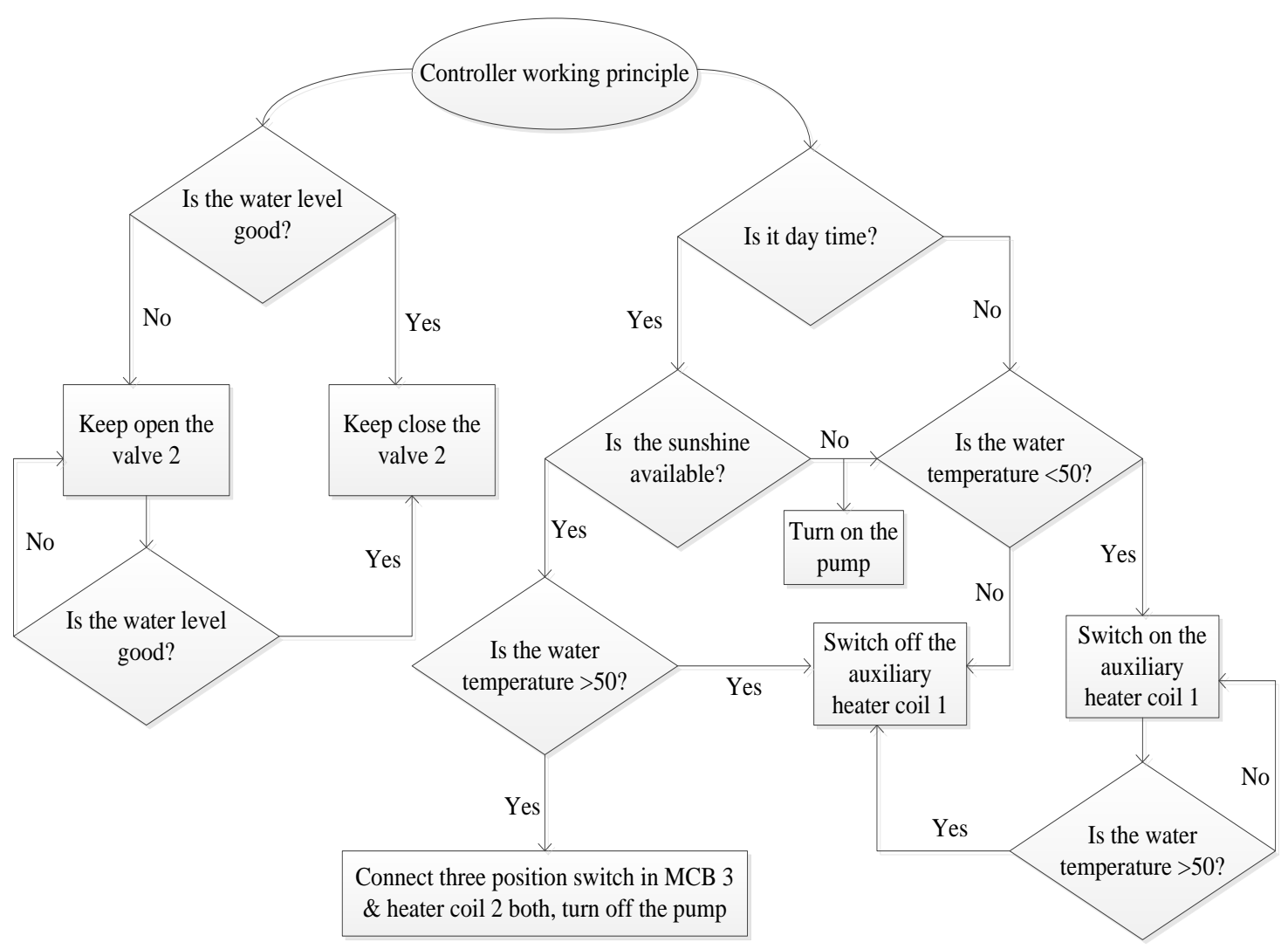

Figure 15. The operating principle of the controller

\subsection{Calculation of the Investment Cost}

The whole system designed and described in section 3.2 3.5. There are factors associated with the installation cost. The percentage of cost distribution, as shown in Figure.16.

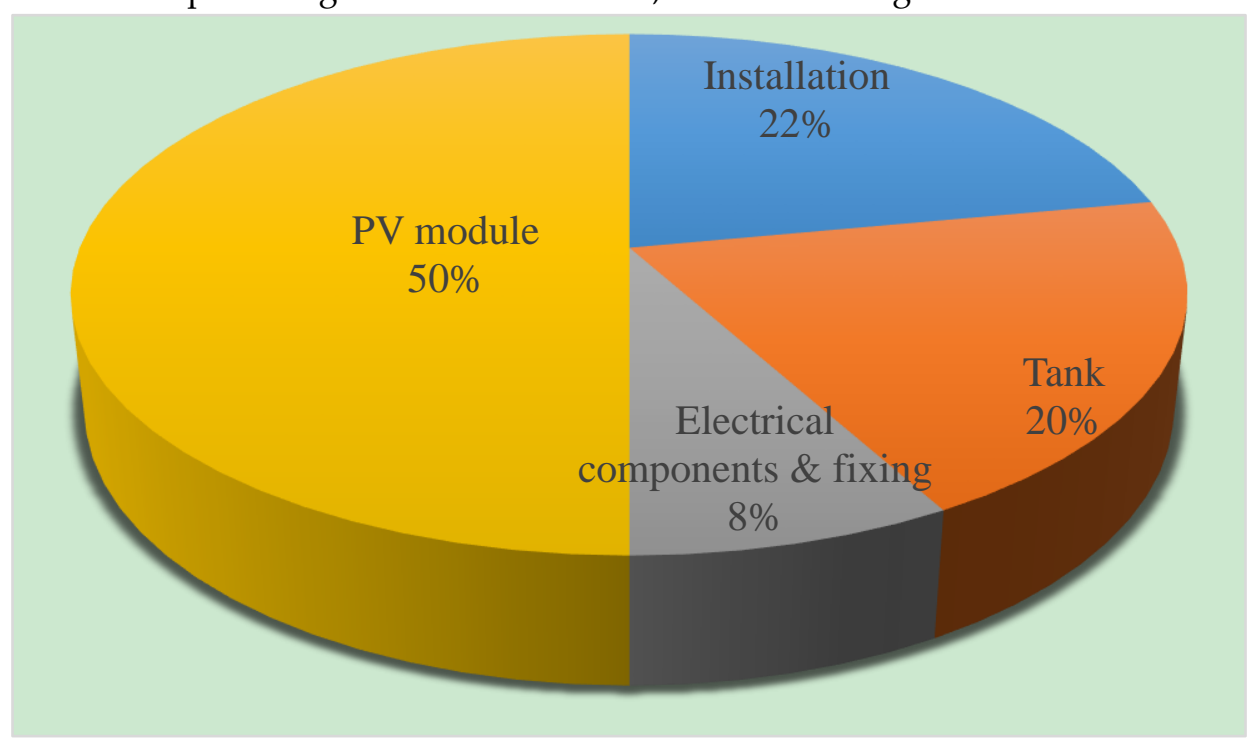

Figure 16. The cost distribution of solar PV based system [22]

The calculation and the total installation cost has been done based on the above design and the latest market price in Amazon.ca. 
Table 5. The cost analysis of solar PV based system based on Amazon.ca.

\begin{tabular}{ll}
\hline \multicolumn{1}{c}{ Descriptions } & \multicolumn{1}{c}{ Sizing and Prices } \\
\hline PV Panel cost & $150 \$ \times 70$ no's=10500 CAD. \\
Installation cost & $10500 \times 34 \%=2310$ CAD. \\
$450 \mathrm{~L}$ of Electric Water Tank with high & $3000 \mathrm{CAD}$ \\
insulation cost & \\
Combiner box (6 String, 250 V AC, 10 A each) & $12 \times 225=2700 \mathrm{CAD}$ \\
MPPT installation & optional \\
Inverter cost (12000 W) & $3000 \mathrm{CAD}$ \\
Electrical components and fixing & $10500 \times 8 \%=840 \mathrm{CAD}$. \\
The total investment cost & $22350 \mathrm{CAD}$ \\
\hline
\end{tabular}

Time to reach the set temperature $\left(2^{\circ} \mathrm{C}\right.$ to $\left.50^{\circ} \mathrm{C}\right)$

Thermal power requirement, $\mathrm{Q}=(4.2 \times 332 \times(50-2)) / 3600=18.60 \mathrm{~kW}$.

Is the two heating element rating is $12.0 \mathrm{~kW}$, then the time needed to reach this temperature is $18.60 / 12=1.55$ hours.

\subsection{Simulation Result}

The total solar PV based space and water heating system described in Figure 14. This complete system has been designed and simulated in the PolySun software environment. The total output of all PV modules without tracking shown in Figure. 17.

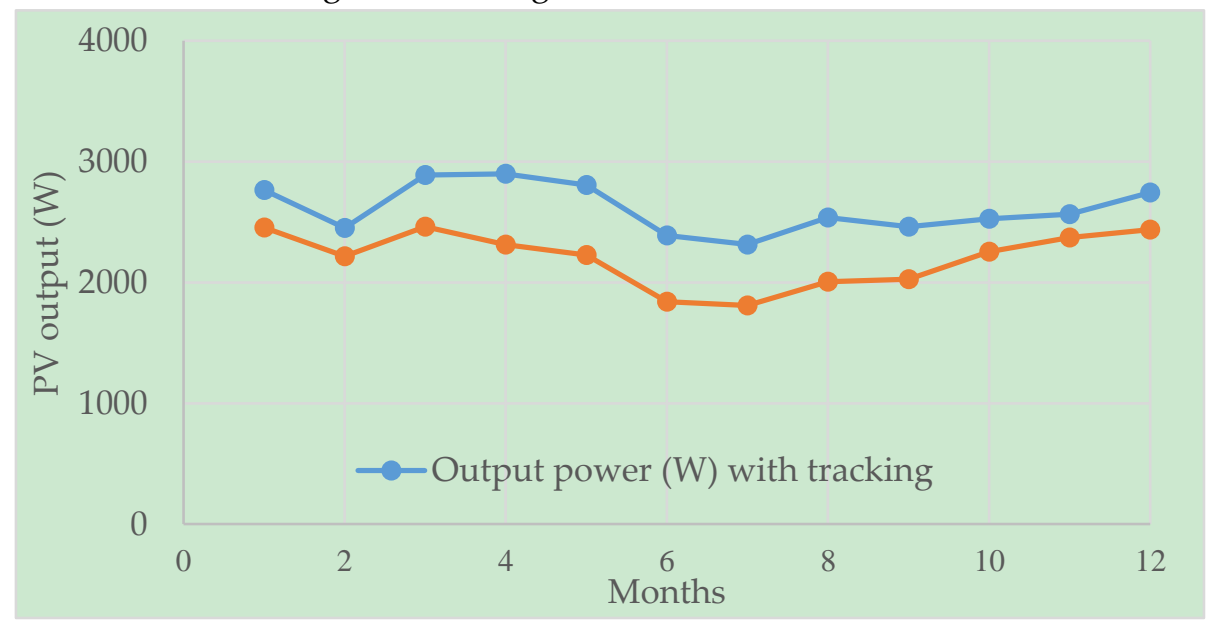

Figure 17. The output power of designed PV panels with and without tracking.

Table 6 . The system output scenario with the MPPT, charge controller and $12 \mathrm{~kW}$ battery

\begin{tabular}{ccccccc}
\hline & & & & & From an & To external \\
Month & $\begin{array}{c}\text { PV output } \\
(\mathrm{kWh})\end{array}$ & $\begin{array}{c}\text { PV Temp. } \\
(\text { Deg. C) }\end{array}$ & $\begin{array}{c}\text { Battery } \\
\text { charge } \\
(\mathrm{kWh})\end{array}$ & $\begin{array}{c}\text { savings } \\
(\text { ton })\end{array}$ & $\begin{array}{c}\text { external } \\
\text { grid } \\
(\mathrm{kWh})\end{array}$ & $\begin{array}{c}\text { grid } \\
(\mathrm{kWh})\end{array}$ \\
\hline Jan & 730 & -1 & 234.8 & 392 & 247 & 305 \\
Feb & 918 & -0.2 & 240 & 493 & 152 & 477 \\
Mar & 1178 & 2.5 & 284.7 & 632 & 96.7 & 646 \\
Apr & 1194 & 6.6 & 249 & 640 & 55.6 & 695 \\
\hline
\end{tabular}




\begin{tabular}{ccccccc}
\hline May & 1302 & 11.3 & 250 & 698 & 13.1 & 795 \\
June & 1331 & 16.4 & 213.4 & 714 & 5.3 & 880 \\
July & 1370 & 22.8 & 213.9 & 735 & 0 & 925 \\
Aug & 1263 & 22.4 & 234.4 & 677 & 0.4 & 808 \\
Sept. & 1104 & 17.5 & 232.1 & 592 & 31.9 & 672 \\
Oct & 836 & 11.2 & 226.1 & 448 & 105 & 421 \\
Nov & 578 & 5.9 & 192.3 & 310 & 201 & 240 \\
Dec & 531 & 1.4 & 194.1 & 285 & 271 & 186 \\
\hline
\end{tabular}

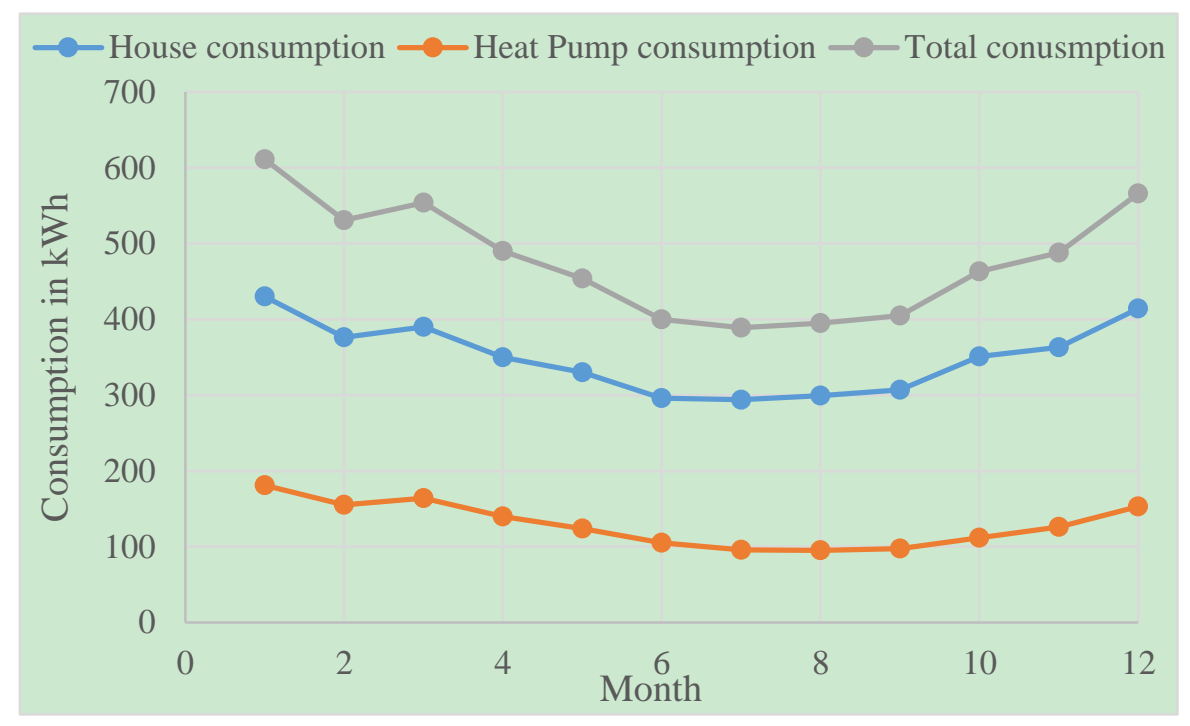

Figure 18. Selected house electrical consumption profile.

The electrical power consumption is given in Figure. 18. It is found that it varies month to month but not more than $600 \mathrm{kWh}$ per months that will mitigate from the batteries when sunshine is not available. The whole system has been simulated again with the MPPT and a $12 \mathrm{~kW}$ DC battery bank with on-grid power system network for storing energy for residential all electrical load appliance. The simulation data with MPPT is summarized and described in Table 6.

\section{Overall Comparison of the Both Systems}

Comparing the design, sizing, cost analysis, output power, rate of return of both system, the final overview has been summarized in Table 7 .

In every year, the depreciation cost has been considered as $5 \%$ and calculated the total annual savings up to 30 years because the lifetime of the system has been considered as 30 years as shown in Figure. 19. It is found that the PV based system is more efficient and economical. 
Table 7. Overall comparison of PV and collector based systems

\begin{tabular}{|c|c|c|c|c|}
\hline \multirow{2}{*}{ Particulars } & Reference & \multicolumn{2}{|c|}{ Thermal Collector Based } & PV Based \\
\hline & & Model 1 & Model 2 & \\
\hline $\begin{array}{l}\text { Power generation } \\
\text { from a renewable } \\
\text { source }\end{array}$ & $0 \mathrm{kWh} /$ year & $4345 \mathrm{kWh} /$ year & $4345 \mathrm{kWh} /$ year & $26412 \mathrm{kWh}$ \\
\hline $\begin{array}{l}\text { Power is taken } \\
\text { from the grid }\end{array}$ & $\begin{array}{c}17009 \\
\text { kWh/year }\end{array}$ & $\begin{array}{l}\text { 9389.5 } \mathrm{kWh} \mathrm{+} \\
\text { 159.2 L Oil }\end{array}$ & $8320.5 \mathrm{kWh}$ & $\begin{array}{l}0 \mathrm{kWh} / \text { year (If net } \\
\text { metering is } \\
\text { implemented) }\end{array}$ \\
\hline $\begin{array}{l}\text { Annaul energy } \\
\text { savings }\end{array}$ & $0 \mathrm{kWh} /$ year & 7619.5 kWh/year & 8688.5 kWh/year & 17009 kWh/year \\
\hline $\begin{array}{l}\text { Surface } \\
\text { requirement }\end{array}$ & --------- & $10 \mathrm{~m}^{2}$ & $10 \mathrm{~m}^{2}$ & $43.94 \mathrm{~m}^{2}$ \\
\hline Storage tank size & $181 \mathrm{~L}$ & $(132+200)$ Liter & $(132+200)$ Liter & $454 \mathrm{~L}$ \\
\hline Investment cost & $\begin{array}{l}\text { Nothing } \\
\text { change }\end{array}$ & $51400 \mathrm{CAD}$ & 51500 CAD & $22350 \mathrm{CAD}$ \\
\hline Yearly savings & 0 CAD (0\%) & $\begin{array}{l}914.34 \\
(29 \%)\end{array}$ & $\begin{array}{ll}1042.62 & \text { CAD } \\
(43.77 \%) & \end{array}$ & $\begin{array}{l}2041.08 \\
(100 \%)\end{array}$ \\
\hline
\end{tabular}

The summation of 30 years annual savings is much more in PV based system compared to the solar collector based system. Besides that, the PV based system needs lower maintenance, and the fittings and other components need less maintenance as well.

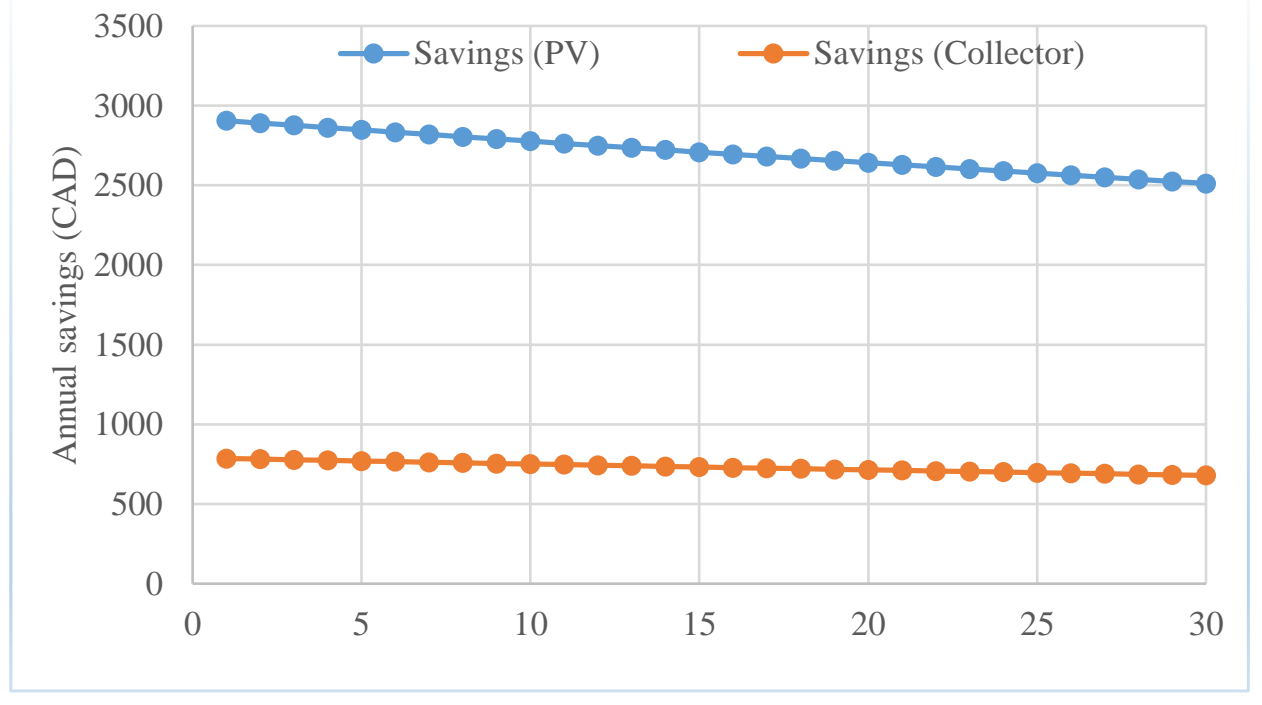

Figure 19. The annual savings comparison of both systems.

The comparison of Figure. 19 has been determined by considering the $5 \%$ depreciation per year. Here it proves that the annual saving is almost 3.5 times of PV based systems compared to the collector-based system over 30 years, and the rate of return is also lower in PV based systems. Although the general efficiency of the solar PV module is around 15 20\% and the efficiency of solar collector is around 60 80\%, but the PV module is much cheaper than solar thermal collector. 


\section{Conclusion}

In Canada, the total $13 \%$ of total electricity is consumed by the residential sector on which $81 \%$ of electricity is consumed for space heating and water heating purposes. By implementing the solar collector based thermal energy storage system, it is possible to save $50 \%$ of electricity. By implementing the solar photovoltaic based system, and it is possible to save $100 \%$ of electricity for residential purposes. From the above design and calculations, it is found that the setup cost of solar collector based system is higher compared to the PV based system, but the output power is much lower in solar collector based system. Recently the cost of PV panel is reduced significantly. This system is also suitable for other house appliances as well. However, it needs more space for PV panel setup. In the selected house rooftop, space is two times of space available compared to the required space or usually all Canadian single-family residential houses have this space. Finally, in overall justification, the solar PV based system is a more suitable, cost-effective, and reliable solution for house appliances, water heating, and space heating purposes. This system can be designed and simulated with solar combi system with a robust controller.

\section{Data Availability}

The meteorological data used to support the findings of this study are included in the article.

\section{Conflict of Interest}

The authors declare that there is no conflict of interest regarding the publication of this paper.

\section{Acknowledgment}

The authors are grateful to the NSERC, Canada, and the Memorial University of Newfoundland for providing the sufficient fund and support of this project.

\section{References}

[1] N. E. B. Government of Canada, "NEB - Results," 15-Aug-2019. [Online]. Available: https://www.cerrec.gc.ca/nrg/sttstc/lctrct/rprt/cnmcsfslrpwr/rslts-eng.html. [Accessed: 21-Sep-2019].

[2] A. Sow, M. Mehrtash, D. R. Rousse, and D. Haillot, "Economic analysis of residential solar photovoltaic electricity production in Canada," Sustainable Energy Technologies and Assessments, vol. 33, pp. 83-94, Jun. 2019.

[3] B. D. Dolter and M. Boucher, "Solar energy justice: A case-study analysis of Saskatchewan, Canada," Applied Energy, vol. 225, pp. 221-232, Sep. 2018.

[4] H. Asgharian and E. Baniasadi, "A review on modeling and simulation of solar energy storage systems based on phase change materials," Journal of Energy Storage, vol. 21, pp. 186-201, Feb. 2019.

[5] “Canada's Energy Future 2018." [Online]. Available: https://www.nebone.gc.ca/nrg/ntgrtd/ftr/2018/2018nrgftr-eng.pdf. [Accessed: 19-Apr-2019].

[6] C. Wadström, E. Wittberg, G. S. Uddin, and R. Jayasekera, "Role of renewable energy on industrial output in Canada," Energy Economics, vol. 81, pp. 626-638, Jun. 2019.

[7] "Renewable energy facts I Natural Resources Canada." [Online]. Available: https://www.nrcan.gc.ca/energy/facts/renewable-energy/20069. [Accessed: 19-Apr-2019].

[8] M. Ghorab, E. Entchev, and L. Yang, "Inclusive analysis and performance evaluation of solar domestic hot water system (a case study)," Alexandria Engineering Journal, vol. 56, no. 2, pp. 201-212, Jun. 2017. 
[9] M. C. Rodríguez-Hidalgo, P. A. Rodríguez-Aumente, A. Lecuona, M. Legrand, and R. Ventas, "Domestic hot water consumption vs. solar thermal energy storage: The optimum size of the storage tank," Applied Energy, vol. 97, pp. 897-906, Sep. 2012.

[10] S. Z. Mohazabieh, M. Ghajarkhosravi, and A. S. Fung, "Energy Consumption and Environmental Impact Assessment of the Energy Efficient Houses in Toronto, Canada," Procedia Engineering, vol. 118, pp. 10241029, Jan. 2015.

[11] J. L. García, C. J. Porras-Prieto, R. M. Benavente, M. T. Gómez-Villarino, and F. R. Mazarrón, “Profitability of a solar water heating system with evacuated tube collector in the meat industry," Renewable Energy, vol. 131, pp. 966-976, Feb. 2019.

[12] T. A. Jesha and M. T. Iqbal, “Thermal Simulation and Energy Consumption Analysis of Two Houses in St. John's, Newfoundland," Procedia Engineering, vol. 105, pp. 607-612, Jan. 2015.

[13] "Borehole Thermal Energy Storage System." [Online]. Available: https://engineering.ontariotechu.ca/research/modern-research-facilities/borehole-thermal-energystorage-system.php. [Accessed: 21-Sep-2019].

[14] F. M. Rad, A. S. Fung, and M. A. Rosen, “An integrated model for designing a solar community heating system with borehole thermal storage," Energy for Sustainable Development, vol. 36, pp. 6-15, Feb. 2017.

[15] J. E. Huguenin, J. L. Chase, and S. R. Chapman, “Development of a seal rehabilitation and marine science facility's seawater and life support system," Aquacultural Engineering, vol. 27, no. 3, pp. 213-245, Mar. 2003.

[16] M. T. Iqbal, “A feasibility study of a zero energy home in Newfoundland,” Renewable Energy, vol. 29 , no. 2, pp. 277-289, Feb. 2004.

[17] “K \& P Contracting Ltd. Custom Home Design \& Renovations, Flatrock, NL," kandpcontractingltd. [Online]. Available: https://www.kp.nf.ca. [Accessed: 17-Mar-2019].

[18] R. Brakels, “Sun Flux Review: Hot Water With Dedicated Solar PV Panels,” Solar Quotes Blog, 24-Aug-2017. [Online]. Available: https://www.solarquotes.com.au/blog/sun-flux-review-hot-water-with-dedicatedsolar-pv-panels/. [Accessed: 19-Apr-2019].

[19] A. Fudholi, K. Sopian, M. H. Yazdi, M. H. Ruslan, A. Ibrahim, and H. A. Kazem, "Performance analysis of photovoltaic thermal (PVT) water collectors," Energy Conversion and Management, vol. 78, pp. 641-651, Feb. 2014.

[20] “National Renewable Energy Report of Canada." [Online]. Available: http://oee.nrcan.gc.ca/publications/statistics/trends07/pdf/Chapter3_e.pdf. [Accessed: 31-Dec-2018].

[21] M. Herrando, A. M. Pantaleo, K. Wang, and C. N. Markides, "Solar combined cooling, heating and power systems based on hybrid PVT, PV or solar-thermal collectors for building applications," Renewable Energy, vol. 143, pp. 637-647, Dec. 2019.

[22] "Solar Thermal Systems Design." [Online]. Available: https://www.crses.sun.ac.za/files/services/events/workshops/03_Design\%20ST\%20Systems_Calculation \%20methods.pdf. [Accessed: 31-Dec-2018].

[23] "NREL Report." [Online]. Available: https://www.nrel.gov/docs/fy15osti/63474.pdf. [Accessed: 17-Mar2019].

[24] X. Xu, W. Hu, D. Cao, Q. Huang, C. Chen, and Z. Chen, “Optimized Sizing of a Standalone PV-windhydropower Station with Pumped-storage Installation Hybrid Energy System," Renewable Energy, Sep. 2019.

[25] M. Baka, P. Manganiello, D. Soudris, and F. Catthoor, “A cost-benefit analysis for reconfigurable PV modules under shading," Solar Energy, vol. 178, pp. 69-78, Jan. 2019. 
